\title{
National Identity and Integration Challenges of Deferred Action for Childhood Arrivals (DACA) Recipients
}

\author{
Sofia Paschero ${ }^{1}$ and Jody McBrien ${ }^{2, *}$ (D) \\ 1 History Department, College of Arts and Sciences, University of South Florida, Tampa, FL 33620, USA; \\ spaschero@usf.edu \\ 2 School of Interdisciplinary Global Studies, College of Arts and Sciences, University of South Florida, \\ Sarasota, FL 34243, USA \\ * Correspondence: jlmcbrie@usf.edu
}

check for updates

Citation: Paschero, S.; McBrien, J. National Identity and Integration Challenges of Deferred Action for Childhood Arrivals (DACA)

Recipients. Societies 2021, 11, 24. https://doi.org/10.3390/soc11010024

Received: 10 February 2021

Accepted: 11 March 2021

Published: 16 March 2021

Publisher's Note: MDPI stays neutral with regard to jurisdictional claims in published maps and institutional affiliations.

Copyright: (c) 2021 by the authors. Licensee MDPI, Basel, Switzerland. This article is an open access article distributed under the terms and conditions of the Creative Commons Attribution (CC BY) license (https:// creativecommons.org/licenses/by/ $4.0 /)$.

\begin{abstract}
Approximately 650,000 children and young adults currently reside in the United States with Deferred Action for Childhood Arrivals (DACA) status, providing them with temporary legal status to reside in the country. We explored the phenomenon of how five DACA recipients experienced their national identities and how it contributed to their acculturation patterns using in-depth semistructured interviews. We interpreted their comments through the theoretical lens of Berry's (1997) acculturation theory and Edensor's (2002) emphasis on everyday life as a critical factor of national identity. Although the participants had the desire to remain in the United States and be a part of U.S. culture, everyday realities of discrimination, and challenges accomplishing common life tasks taken for granted by American peers (getting a driver's license, travelling, working, obtaining financial aid for higher education) kept the participants from fully integrating into American society and gaining a sense of belonging.
\end{abstract}

Keywords: DACA; undocumented immigrants; identity; acculturation; integration

\section{Introduction}

In April 2001, the first author was six years old, living in Mendoza, Argentina. She boarded a plane with her mother and brother bound for Buenos Aires. From there, they flew to Florida. It never occurred to her that she would not be returning. Her family left everything behind to start a new life in Florida.

In the United States in 2019, nearly 650,000 Deferred Action for Childhood Arrivals (DACA) children and youth feared deportation to lands they do not remember. Meanwhile, they struggle to integrate into a society where many citizens indicate they do not belong. Politicians and laws may punish them as adults, but as children, most had no choice when they immigrated [1]. These young people participated in U.S. culture by growing up with American children, sharing the same education, singing the national anthem, and pledging to the American flag. (Note: We find the use of "American" to refer to the United States problematic, as countries in both the North and South American continents are technically American. However, we recognize common usage of America/American to refer to the United States and U.S. citizens and have used this language in our article.)

Such challenges complicate immigrant youths' sense of national identity and ability to integrate. Our research provides data from four individuals who currently have DACA status and one individual who had DACA in the past but now has permanent residency. Given anti-immigration sentiment in 21st century America resulting from such events as the 9/11 attacks and actions taken in 2017 by the Trump administration to eliminate the DACA program begun by President Obama in 2012, such research is needed to clarify the challenges faced by undocumented youth with respect to social integration and the precariousness of inclusion and belonging resulting from a tenuous national classification. 
We examined how being immigrants before and after the passage of DACA affected participants' sense of belonging in the United States [2]. We explored when they felt "American" and when they felt "un-American". Obstacles included school/financial challenges, discrimination, home, travel, obtaining a driver's license, applying for college, and applying for a job. We considered how these obstacles shaped their ability to integrate into US society.

The first author understands these obstacles, because she has experienced them. She applied for DACA in 2012 as a high school junior. At a young age, she understood that she did not have the same opportunities as her U.S.-born classmates. Such challenges contributed to her conflicted sense of belonging and identity. For clarity, in the Results section this author will use first-person pronouns.

\subsection{Literature Review}

Much of the literature on immigration conflates identity and acculturation [2-6]. This is not surprising, as one's sense of self is embedded within a sense of belonging, which extends from the most intimate of family groupings to identifying with one's race, ethnicity, gender, nationality, and more. The participants in our study refer both to their identities and their feelings about how they fit into American society.

There are many important studies on the identities of immigrants $[4,7,8]$. However, much research on DACA individuals is tangential to our research questions. For instance, Patler and Pirtle [9] examined psychological wellbeing of young Latino adults before and after a transition from undocumented to lawfully present status. Change from undocumented to lawfully present status was associated with positive health outcomes. The researchers concluded that Latino immigrants face a unique set of stressors due to their stigmatized minority status and that a lack of legal status impacts health and wellbeing.

Siemons, Raymond-Flesh, Auerswald, and Brindis [10] also examined the mental health and wellbeing of young immigrants. They found that immigrants face significant stress both during and following migration, regardless of legal status. They categorized results into community, interpersonal, and individual levels. At the community level, participants reported that DACA status smoothed their transition into U.S. society. Without DACA, participants reported significant stress. In both cases, however, they faced challenges. For instance, they were disqualified for coverage through the Affordable Care Act and did not qualify for financial aid. At the interpersonal-level, DACA recipients were able to share experiences with other young adults. At the individual-level, participants stated that DACA status gave them some sense of belonging. However, since it is temporary, it caused individuals anxiety. Recipients felt stalled by a system that does not allow full participation in the United States. This made them feel that they do not belong in America, and it had negative implications for their personal wellbeing [2].

Some studies examined bifurcated senses of identity and belonging. For instance, Tafoya et al. [11] studied connections between undocumented Latinos' political activism and their social identities as Americans. The researchers indicate that undocumented children arriving at early ages have a tendency to become politically active as a way of creating an American identity. Many participants in Tafoya's study noted that they only learned of their undocumented status as adolescents when they tried to get a job or register for higher education and learned they could not, because they could not receive a social security card (prior to DACA; see also Monico \& Duncan [12]; Rosenberg et al. [13]). They also noted that they had little knowledge of their countries of origin and that they "felt" American. Benuto et al.'s [14] qualitative research with Mexican immigrants found that participants felt they did not belong until they received DACA status. However, as DACA still limits full access to various benefits of American citizenship, they struggled again with their sense of identity [14].

Similarly, DeAngelo, Schuster and Stebleton's [15] research focused on how undocumented students' identities are shaped by activism (see also Chang et al. [16]). This research described a young activist named Ana who described disadvantages faced by 
undocumented college students. Ana suggested that undocumented individuals' identities are changing because they are now advocating for themselves. Another form of activism involved participants taking the role of mentors to help other undocumented youth [15].

This theme of belonging is also affected when DACA students feel as though they are misunderstood, and even invisible. Muñoz and Vigil's [17] research discussed institutional ignorance, the reproduction of pervasive invisibility, and hidden communities of support. They found that higher education staff lack knowledge regarding immigration laws to help undocumented and DACA students successfully navigate their university needs. As a result, immigrant students often take on educator roles in addition to their student responsibilities. For instance, they may educate faculty about undocumented and DACA students [18]. DACA students are classified as international students despite not living in their country of origin. This suggests to DACA students that they are neither equal to their classmates nor a priority in higher education.

Additionally, the lack of welcoming behaviors from US citizens also contributes to challenges to belonging. Bozorgmehr, Bakalian, and Salman [19] researched hostility of native populations towards newcomers. Swan and Clark-Ibanez [20] examined how DACA university students struggled with "legal violence" pertaining to their status, and how these issues resulted in "psychological and social burdens for undocumented students" (69). The researchers concluded that participants recognized DACA as an immediate, though temporary benefit to their lives. However, they also realized that they were seen as unlawful by society and that the U.S. legal system did not offer them protection. They struggled to succeed academically, while also trying to maintain a job and keep their families intact. Abdelkader [21] has also written about xenophobic policies and practices promoted by the Trump administration and held by a majority of Republicans, which stigmatize minority populations in the U.S.

\subsection{Theoretical Framework}

As we examined a comingling of identity and integration constructs, we were guided by two compelling theories. Acculturation, the 'process of change that results from continuous first-hand contacts between people from different cultures' [22], is foundational to how immigrants perceive their identities in a new nation.

In spite of criticism to his theory [23,24], we find Berry's [3] theoretical work foundational to our research. Berry observed that there are four types of acculturation. Ideally, immigrants are able to integrate, meaning that they can maintain connections to their primary culture as well as adapt to aspects of their new culture that help them to settle, gain good employment, and be comfortable in their new surroundings.

Berry [3] also described less-than ideal ways in which immigrants may resettle. Assimilation is when immigrants choose to discard their original identity to replace it with the culture of their new nation. In contrast, separation means rejecting the culture of the new homeland to remain loyal only to their culture of origin. This is a label that native citizens often place onto immigrants, believing that newcomers do not want to learn the language or customs of their new country. Finally, this paper explores marginalization. This is a problematic identity in which migrants feel unconnected to either their home country or their new location.

Identity is a complex concept typically described in psychosocial terms. Given that place is such an important element of migration, and especially for immigrants whose sense of place is disturbed by uncertainty, we were drawn to Edensor's [25] emphasis on "everyday life" as a critical factor of national identity. He states, "national identity is grounded in the everyday, in the mundane details of social interaction, habits, routines, and practice knowledge" (p. 17). As we analyzed comments by our participants, they clearly rooted their sense of belonging in American society (or being marginalized) by inclusion or exclusion from the everyday activities that were taken for granted by their American peers. 


\section{Materials and Methods}

Our research was qualitative analysis involving purposeful sampling of DACA youth utilizing in-depth semi-structured interviews. Qualitative research allowed us to consider nuanced perspectives as well as a comprehensive set of themes [26]. Ours was a phenomenological study, as we attempted to understand the reality of our participants' experiences and feelings about their DACA status through their in-depth descriptions of how life events related to their acculturation and sense of belonging in the United States [27]. We used variations of Moustakas' [28] phenomenological interview questions: What have you experienced as a result of your status in the U.S.? and What were events that affected your experiences of this status? Participants expressed how it felt to be an undocumented immigrant and having DACA status. They described how obstacles resulting from lack of documentation shaped their identities and acculturation. We strengthened the authenticity by selecting DACA individuals who were brought to the United States as children and now are adults, and through the insider status of the first author, who is a DACA recipient [29].

\subsection{Participant Information}

This study included four young individuals with DACA (including the first author), and one individual who had DACA but now has permanent residency (see Table 1). All participants are over the age of 18. They arrived in the United States before the age of 12. All came to the United States with a visitor visa. Three have renewed their DACA for another two years. Their average time in the United States is 17+ years. The five participants represent two different countries from Latin America: Argentina and Mexico. Three participants are male and two are female.

Table 1. Participant Demographics.

\begin{tabular}{cccc}
\hline Participants & Arrival Age & Current Age & Country of Origin \\
\hline Alejandro & 4 & 22 & Mexico \\
Carol & $8-9$ & 26 & Argentina \\
Hady & 5 & 23 & Mexico \\
Nick & 11 & 28 & Argentina \\
Sofia & 6 & 23 & Argentina \\
\hline
\end{tabular}

We recognize that the number of participants is small. However, phenomenology requires that participants be part of a relatively homogenous group [27]. Ours were all Latinx participants from Central and South America. It is difficult to gain a large participant pool when the phenomenon being studied is one that many with the experience choose to hide to protect themselves, especially when the study is bound by time and geographical limitations as ours was. Polkinghorne [30] stated that numbers of participants for phenomenological studies vary greatly, He provided an example of an exemplary study that included only three participants.

\subsection{Data Collection}

The first author collected initial data by conducting interviews: three were conducted face-to-face, and one was conducted over the phone. She used autoethnography to answer the questions about her own life. The research was conducted during the summer and fall of 2019. Questions explored participants' experiences adjusting to life in the United States, the impact of immigration status on their educational and career pursuits, and their expectations for the future. Interviews also covered how they still faced obstacles, how they overcame them, and how it changed their identities. The time limit for first interviews was a minimum of $40 \mathrm{~min}$ and a maximum of one hour. The first author also conducted follow-up interviews to address questions remaining after the researchers read the initial transcribed interviews. Follow-ups lasted approximately $30 \mathrm{~min}$ each. 


\subsection{Ethics}

Approval from the Internal Review Board (IRB) was granted before interviews were conducted. Participants picked pseudonyms to protect their identities. They met the first author at specific locations convenient for them to be interviewed.

\subsection{Data Analysis}

The first author transcribed the digitally recorded interviews. We read through the data and hand coded all interviews. We interrogated our codes by using nVivo wait to confirm trends in the research. We reduced categories by grouping topics that related with one another into themes [31]. The two authors coded the data independently along with a peer of the second author to reach high inter-rater reliability. The final step in our data analysis involved interpreting the meaning of the research themes.

We grouped codes into the following themes, discussed in the results: Language, discrimination, school challenges, financial challenges, equality, national identity, DACA status, concepts of home, identifying as American, and cultural identity.

\subsection{Study Limitations}

As is the case with all research, this study has limitations. The sample is small, and it only includes DACA participants from Central and South America. None of the participants presented with intersectional identities such as LGBTQ or disabled. We hope that future opportunities not hampered by time restrictions will allow us to broaden our study to include additional variables that could add nuances to the current research.

\section{Results}

The findings section is divided into two parts: (1) Before DACA (undocumented), and (2) after receiving DACA status. The first author asked participants to begin describing their experiences as undocumented immigrants and finished with questions about current life. The major themes coded throughout all interviews were language barriers, discrimination, school/financial challenges, equality, home, defining Americans, media/politics, and national identity/cultural identity.

There are several years' age difference between some of the participants that account for some differences in responses. For example, Nick graduated high school in 2007 and Carl graduated in 2010. Since DACA began in 2012, their experiences in applying to higher education were different than what Alejandro, Hady, and the first author experienced, all 2014 high school graduates. The younger three already had DACA in their junior year of high school; Carl and Nick did not. Nick is the only participant who has permanent residency status; everyone else currently has DACA.

\subsection{Before DACA}

\subsubsection{Language Barriers}

All participants had similar experiences learning English. Research shows that young arrivals will initially struggle with language, but it is easier for them to learn a second language than adolescents or adults [23]. Alejandro spoke about his early experience with English. He said:

My first language is Spanish, I didn't know any English. I went to a day care when I was four. My mom told me that I was like, I don't wanna go, because I didn't understand what they were saying.

Carl said that during his first few years in the United States, he went to an American school, but the teacher was Puerto Rican, so Carl and his classmates could speak Spanish. Once his family moved to another state, everything changed. Carl explained, "The school was difficult because it was all in English. I didn't even know English the first few years". He explained that the language barrier embarrassed him and prevented him from making American friends. 
Hady also struggled with English when she first arrived. Her mother told her that she frequently cried after school. Hady told her mom that she did not like the way children talked at school because she could not understand them.

Nick explained that even Mexican students would harass him because he was the new kid in school who did not know English. He told a story about a time in high school when he spoke Spanish to a classmate:

I was talking to a friend in Spanish, in a class that was mostly white folks. One kid said, "You better speak English, I won't tolerate that in my country". I got in his face and he backed down quick. Nobody ever said anything again. Most of the kids were minorities. I didn't really feel that much different.

I (1st author) remember having a hard time understanding people when they spoke English. When I first attended an elementary school, my teacher paid little attention to me because she did not know Spanish, so she could not help me. I cried a lot as a small child because I had a hard time with the language and the transition.

In elementary school, I had an experience similar to Nick's. When I spoke in Spanish to a friend, some students complained. At home, I spoke in Spanish, but outside the house, I had to speak in English. Once as a child, I started speaking in English to my brother. He told me he could not understand me. This was his way of saying that he did not want me to lose my native language.

\subsubsection{Discrimination}

Participants often sensed discrimination through American's actions and words. Carl and Hady were asked for their identification cards (IDs) and questioned about their legal status. Alejandro fielded negative comments for being Mexican. Nick felt discriminated against when he applied to a community college. Alejandro stated that people who knew that he was undocumented made comments such as, "Do you have your Green Card?" and "Go back to Mexico". Hady was uncomfortable when students in class talked about immigrants.

Carl described a dentist visit at which the receptionist asked for his driver's license. He explained, "They asked me, 'How did you drive here?' They were being offensive". He drove to the dentist without a license. This experience made him feel unwelcome.

Hady recalled a time in the car when her father got pulled over. The police officer asked for her father's driver's license, but he did not have one. Then, the officer asked for Hady's ID. Hady stated, "I showed him my DACA card, because I didn't have my [driver's] permit yet". The officer asked her where she got the DACA card. She explained that it was a Congressional policy. After making calls in his car, the officer returned and said, "Be careful. We want you guys to be legal here, so get your citizenship". She and her father said to themselves, "Yeah, like it's that easy".

Nick felt discrimination when he applied to a community college and was denied. He was 17 years old, and the college denied him because he was not born in the United States. Nick said he had similar experiences when applying for jobs.

Before I (1st author) had DACA, no one said anything that made me feel personally discriminated against. However, in middle and high school, when the topic of immigration would come up, classmates always had something negative to say. I remember thinking that no one there knew that I was an immigrant. It would be hard to say something in front of a class of all white Americans in which I was the only Latina.

\subsubsection{School/Financial Challenges}

In this section, Alejandro, Hady, and (1st author) do not comment, because when we applied to higher education we had DACA. Carl and Nick faced challenges applying to and paying for higher education when they were undocumented.

Carl had to pay out-of-state tuition in the community college he attended because he was considered an international student. He described a few private scholarships he applied for, such as Hispanic Achievers from the YMCA, which he received. However, 
he said, "It wasn't enough to even cover two or three out-of-state tuition courses". He received additional help from a Community Foundation scholarship. In total, he received about USD 7000 from non-profit scholarships. The rest he paid out-of-pocket and from bank loans.

Nick explained that the scholarships he received were insufficient. He stated that universities charged double what they charged an American student: "A thousand-dollar scholarship was not enough". Nick said that after he graduated high school, he went to a technical school for a few months and then had to drop out. Nick explained, "The economy went down in 2008. I had to start working at a fast food restaurant".

\subsubsection{Equality}

Participants felt unequal to their American classmates when they were undocumented, especially in high school. Alejandro explained that he felt equal before high school. Then, peers began getting driver's licenses and jobs. He said,

That's when I felt unequal, 'cause I couldn't get a job, I couldn't get a driver's license. I wanted to drive, just do normal things. A lot of people went on vacation, they could travel. And [back] then, I was not able to ... . I was definitely conscious of my status and how I ... fit in society.

He would say to himself, "Why can't I just be like everybody else?" He felt he had to lie about having a driver's license. Whenever anyone asked, his reply would be, "Oh, I haven't gotten it yet because I don't need one". Alejandro stated, "I had a lot of friends who were lazy and didn't get one either. So, I went along with them".

Carl explained that he never saw himself as illegal. The first time he felt unequal occurred in his college years. He wanted to apply for a sales job but could not, because he was undocumented and did not have a social security number.

Hady said that when she got to high school, she realized that she was different from an American citizen. Her father told the family, "I gotta be careful, or what am I going to do with the business?" He father delivered vegetables with a truck, so he had to avoid getting pulled over. That is when Hady understood that she would not be able to get a driver's license.

When Nick was undocumented, he felt unequal to American citizens. He stated, “Wasn't able to get a regular job. Was charged as a foreign student when I only lived 20 min from my community college. Couldn't get a driver's license. Didn't have social security or health insurance". His status struck Nick was when he was 16 and some of his classmates started getting driving permits.

I (1st author) felt equal to an American citizen when I was in middle school. Students and teachers knew that I was from Argentina, but they never asked me about my legal status. Similar to the other participants, I started to feel unequal when students started to get their driving permits and licenses. My classmates asked me why I never drove, and my response was because my dad would not let me. This was not a lie. My dad honestly would not let me drive, because he was afraid I would get pulled over and reveal that I had no license. I remember classmates making fun of me for not having a driver's license. That made me feel unequal.

I also felt unequal when it was time to apply for higher education. Students were applying for the Free Application for Federal Student Aid (FAFSA), and they talked about going out of state. I could not do that.

\subsubsection{National Identity}

The themes described above contributed to shaping each participant's identity when they were undocumented. Carl and Nick were affected the most. Carl explained,

When all of this was happening, I did not see myself as an American. You feel like an outsider, but most of the time you have a set of friends who support you. You see yourself as someone who needs to continue fighting and trying to succeed. I had a really good set of friends, and we would encourage each other. 
Nick stated that he never felt equal to his classmates, and only felt equal to people in the same situation as he. I (1st author) also felt like an outsider. I knew that I did not belong in Argentina, because I did not grow up there. Fortunately, I had a friend in the same situation. It was good to talk to her about it because my American friends did not understand. They thought that anyone could get citizenship and be approved in less than a month. I eventually gave up on trying to educate people, because they thought that they knew more about the immigration laws than I did.

As a junior in high school, I (1st author) worked for an after-school dance program as an instructor and choreographer for about 200 elementary school students. My boss said I needed a certain clearance to enter elementary schools and teach by myself. I had filed for DACA, but not heard back from USCIS (United States Citizenship and Immigration Services). I could not apply for the clearance because I did not have a social security number. My boss wanted me to call USCIS to speed up my application process. I said that was not something you can ask immigration to do. Eventually, I was approved, received a social security number, and was able to apply for the clearance.

This was when it struck me that being undocumented could be a real struggle. I realized that I was not a true American because I did not have legal documentation. I could have lost that part-time job because I did not have a social security number.

When I was in a junior in high school, a woman who worked in my high school told me about a program that helped first generation, low-income students attend college. Once I received DACA and my social security number, I applied to the College Reach-Out Program (CROP) at a state college. It paid multiple semesters of my community college tuition. If I had never filed for DACA, received a social security number, or filed for the CROP program, I would have never been able to attend college. In a way, DACA saved me. It gave me some rights. I finally began to feel like I belonged in America.

\subsection{DACA Status}

Although all five participants felt some sense of relief after President Obama announced DACA policy in 2012, they continued to have everyday challenges not faced by their American peers, as well as fears and uncertainties about their status, given that DACA is provisional. For instance, they still did not qualify for the Free Application for Federal Student Aid (FAFSA) or health care through the Affordable Care Act. Only Nick has permanent resident status.

\subsubsection{Discrimination}

Once all five participants received DACA, they said they felt less discrimination. At the same time, their remarks alluded to fears based on discrimination. Alejandro provided a story about one of his friends, demonstrating this concern. He said,

My friend's name is Johann. One day I saw his wallet when we were at a burger place. He had a work authorization card. I'm like, "Are you DACA?" He's like, "How did you know? I never share that with anybody". I said, "Because I'm DACA, too". I'm really private, I usually don't tell anybody. I try to blend in.

Their responses indicate a desire to create a blended identity as described by Berry [3]. They also indicate a sense of fear, as these individuals had been friends for several years, yet never revealed to each other that they were DACA recipients.

Both Carl and Nick had a different take, based on social oppression. Carl indicated frustration that lawmakers took so long to help the young Latinos in the country who wanted to go to school and get jobs. He was upset that it cost him so much to go to school, but he was grateful that DACA was finally instituted. As such, he suggested a desire for integration, but also a sense of separation, not necessarily on his part, but that of the host country.

Nick said he did not feel discriminated against once he had DACA. However, he still felt oppression, saying: "Once I had DACA, things got better for me. I had more rights than when I was undocumented. However, I felt oppressed when President Trump rescinded 
DACA". His response indicated a response not found in Berry's [3] framework, that of alienation, or rejection by the host country.

\subsubsection{School Challenges}

Although Alejandro, Hady and (1st author) had DACA, we still faced challenges in secondary and higher education. Alejandro described his initial thoughts about higher education, stating: "At first, I wanted to be a cop. I thought it would be quick and easy. I didn't have a lot of money to go to college so decided to choose something like a two-year degree". Then, he realized that one had to be a U.S. citizen to become a police officer. He felt cheated.

Alejandro became a finance major. He stated, "I try to look on the bright side of things. It paved a way for a new door to open. I love the stock market. I hope to start a business one day. Doing something to help others, manage money, invest in stocks, or whatever".

Alejandro explained what happened when he applied for FAFSA for the first time. $\mathrm{He}$ was awarded USD 5775 dollars, but within a week it was rescinded. FAFSA staff told him that he was not eligible because he had DACA. Alejandro stated,

They said, Congratulations, you're awarded $\$ 5,775$. A week later, they were like, We made a mistake, you're not eligible because you're DACA. I didn't know that I was not eligible. Why did I just waste my time for all of this? I was really mad. If I were a citizen or even a resident I would have had my community college paid for 'cause that's how much it cost. Worry set in. Like, how am I going to pay for college? I knew my parents couldn't afford it.

Alejandro was able to receive a bank loan. He noted, though, that some bank officers told him they would not give loans to DACA students. Hady described an offer to go to France in high school. She said:

I knew I couldn't. I can go, I just can't come back! I remember saying, “Oh, my parents don't want me to". I lied, did not tell them about my immigration status. I was recently invited to go back to my birthplace. I said, “No, I can't because of my status. I can't leave the country". Now I am a little bit more open about it. I'm not ashamed. It's the truth.

Hady stated that she was upset and a bit ashamed that her friends were traveling, and she was left behind. She said she did not like to give reasons, because people did not understand. Regarding financing higher education, she said,

I couldn't apply to the Florida Bright Futures scholarship, because I'm not a citizen. Or another scholarship: you have to be from here. I was like wow, there's a lot of things I didn't know I don't qualify for. There were lots of things where I felt I was on my own. Everybody else was from here and it's easy, but, well, that doesn't apply to me.

Hady's experiences indicated a desire for integration, but a rejection based on U.S. policies, which could lead to separation. Based on her interview comments, her preference was for integration.

I (1st author) also faced challenges with higher education. For example, I was told that I did not qualify for FAFSA. However, the community college I went to still made me apply for FAFSA every year. It was a way to show proof that I was unable to receive money from FAFSA and for scholarship benefactors to see that. That way, they would give me money to go to school. I was mad when I heard a few friends who were U.S. citizens had leftover money from FAFSA. They spent it buying material things that were not even for school. I also got mad when those students were given the opportunity to go to school for free but they dropped out, while I was struggling to find a way to pay for school.

Another challenge I faced was in two different departments at the university that I attended as an undergraduate. Before President Trump rescinded DACA, I renewed and was approved. I brought my new I-797 to the admissions department of my university to upload into the system. The admissions staff told me that the Global Engagement office had to upload it. When I went to that office, a staff member was very rude to me. She asked what I was going to do about DACA. I clearly had a renewed I-797. She stated that 
President Trump had ended the program. I told her that I renewed before he ended DACA. She replied, "It will eventually affect you".

Next, I faced a challenge with financial aid. I wanted to speak with someone about scholarship opportunities for a master's program at a Florida state university. I explained to the advisor that I have DACA status. He said, "You need to apply for citizenship," indicating a complete lack of understanding about DACA. He said that I should go to a private bank and request a loan. He had no knowledge about DACA students in higher education.

\subsubsection{National Identity}

Participant comments indicated different viewpoints on how DACA has shaped their identity. Their experiences affected how they think of "home," their cultural identities, and whether they feel American or not American.

Home

Comments about daily life included many descriptions of "home". Participants' statements about the locations they chose as their homes provided information about their national identification.

Alejandro said that his home is in Florida. When asked, "Is Mexico your home?" Alejandro said, "No, because I don't know anything about it. I don't remember anything". When asked what he says when people disagree with him, Alejandro stated, "I grew up here. I don't know any other home. I usually don't argue with ignorant people".

Carl also stated that the United States, Florida especially, was his home and where he was finishing his B.S. in computer engineering. When I suggested that some people would disagree with him, Carl stated,

I could say many things. I contribute to society in many aspects. Not just paying taxes, but working for U.S. companies. I've been here for as long as I can remember and I've gone through education here. Most of my time I spend working to pay for stuff in the US. I am a contributing member of the society so that is why I call this home.

Hady felt similarly. She stated that her family raised her in Florida, and she worked, studied, and made friends here: "This is where everything has happened in my life. I don't have to be born here to make this feel like my home".

S_, Florida is my home because this is where I (1st author) grew up, went to school, and worked, and because my family and friends live here. As a history major, I can provide details about U.S. history. This is something that many Americans could not do; yet, I know, and I am the immigrant. If I were to go back to Argentina, I would feel out of place.

Nick's response indicated a definite sense of integration, more than the other participants. He said, "My home is in Florida and Argentina, because I feel comfortable in both places. I feel like both places are home". Nick concluded that Argentina and the United States were both his homes because he was able to travel back to Argentina where he was welcomed by family and friends. As Nick left Argentina at age eleven, he remembered more about his country of origin than the other participants who immigrated at younger ages. This information indicates that one's sense of identity may depend on time spent in both the native and the new country.

Nick also said, "I feel that this is home, so I want every single piece of paper in writing saying that his is my home and that nobody can kick me out of here". This comment suggests an assimilationist identity.

Who Is an American?

Participants suggested different definitions about being an American, which also spoke to their self-identity. They also stated how they fit or did not fit into that definition.

Alejandro said that for him, being an American was having freedom: living his life as he chose to; doing things for the community; living peacefully; and not being judged based on color, status, religion, or background. He said that not everybody believed that now because of events happening in the United States. Alejandro stated, "Basically [it is] proud, patriotic, and stands for a huge melting pot where everybody stands with each 
other". Asked if he fit into this definition, Alejandro said, "I would say 99\%. Having the sense of freedom, everybody has their own opinion and I respect that. That's huge for me".

Although Alejandro immigrated at the age of four, he did not completely feel American because of what was being said about immigrants at the time. Alejandro stated,

I definitely consider myself American. I grew up here and if I was to go back to Mexico I would be lost. This is my home, and this is where I'm meant to stay. As far as feeling American? Probably not. I feel like the system has corrupted people into thinking that immigrants are bad, not good for this country ... Obviously, the president [Trump] is not helping. That makes me feel like I'm not wanted here, so I don't feel like I'm part of them.

This identity framework indicates the desire to integrate, but rejection by the native population and politics prevent Alejandro from feeling accepted.

Hady defined herself as an American. She said, "I think an American is someone who appreciates the United States. Someone who has lived here to know that. Someone who will defend the United States. They have patriotism". She said she fits that definition. Even though she loves her Mexican heritage, she felt American. She said that DACA was one of the things that she was most grateful for and that having a social security number gave her a national identity. Hady stated, "I am someone with an identity in the United States. I am not someone that is unknown". This statement indicated an assimilationist approach to identity.

Carl described a hybrid identity. He explained that DACA gave him opportunities to work, travel, and be safe. However, he stated that he connected more with Latin culture and Latin Americans. He stated,

Always, I call myself Argentinian and would always call myself Argentinian when it comes to the traditional values. But I don't watch politics from Argentina. I listen and read politicians from here because I care about what's happening here.

His description lent itself to a separation identity. However, his comment on the importance of U.S. current events suggested some integration.

Carl provided a profound definition of an American and stated how he fit into that description. He said:

An American is an immigrant really, who got here somehow. The United States of America was always a land of immigrants. A real American knows that. The ignorant ones believe that they're American because they were born here, but the ones who understand are the ones who know that their past ancestors are not from this country. They actually came from Europe, they came from South America, the Caribbean, everywhere in the world.

You know how they call people first generation, second generation? I am like how in 1900 when people came from Germany or Italy, and they went to Brooklyn and they had kids there. I am them from now. The millennial that also got here will eventually have a family and contribute to society. I fit what America was always established as. I am the immigrant that is creating that under stage [for future generations of my American family].

My (1st author) sense of belonging is similar to Carl's. In one way, I feel American, given I have spent most of my life in America. Still, I do not feel equal to an American citizen because I do not have the same rights and freedoms. To me, an American is someone who lives in the United States and abides by the rules of this country. America was founded by immigrants over 200 years ago. Americans today tend to forget that. I fit into the immigrant definition because I have lived in America for eighteen years of my life. I grew up with American people. I am a contributing member of this country.

Nick's reflections on U.S. identity related to politics. He said, "I can't say I belong because this guy Trump came out and said that he was going to take us out. You can't really feel like you belong when someone is threatening you to take it away".

Nick said that being outside of America was what made him feel more American. Nick was able to leave the United States and travel to Argentina because he was a permanent resident. He said, "My mentality has changed in such a way that I don't think like Argentinians. My mentality is very Americanized, but I won't feel American until I 
am an American citizen". As such, he straddled an identity between assimilationist and integration.

Nick's definition of an American was very different from the other participants. His response sounded like one that an American citizen would give. Nick said, "Someone born in America or someone who has gained the right and is already an American naturalized citizen". I asked Nick if he fit that definition and he said not at the moment, but that he hoped to fit eventually.

\subsubsection{Cultural Identity}

Similar to national identity, cultural identity is an important theme in this research. All participants alluded to their primary culture when describing their American identities. Alejandro stated,

I consider myself Mexican American. I love all the traditions. My family has shown me what it is like to be Mexican. You don't want to let go-it's your past, and you always have to remember where you come from. I'm American because I was raised here. I don't know any other home. I consider myself American, even though I am not legally an American.

For Alejandro, his cultural backgrounds did not conflict with one another. In the interview, however, he stated that he did not feel American because of how divided the country was at the moment and how some Americans expressed their views on immigration.

Carl's response was very similar to Alejandro's. Carl said,

I'm South American. I like family values and being around the family and knowing I'm Argentinian, but at the same time, I connect with young Americans ... I [identify] with the family values of being a South American, but also the American who is politically active.

Carl explained that the length of time he had spent in the United States made him feel American. Simultaneously, he felt Argentinian because he was born there, and he had a strong sense of the culture. He also explained the role of language in his blended cultural identity:

I have the most fun when I'm speaking Spanish with other South Americans and we can relate in that aspect. At the same time, if I have to explain some ideas or processes, things that I do, or the job that I do, I use English, because that is the language that I learned it in. You have to have dual identities sometimes because it's difficult for me to explain technical things in Spanish. When it comes to feelings and thinking, it just gives me a better feeling to communicate in Spanish.

Carl's comment described an integrative style of immigration, as he projected respect for both his homeland and his newcomer country.

Hady said that she would be lying to call herself American, because she was not an American citizen or a permanent resident. Still, she felt American. Hady's response to the question about her identity bordered on marginalization, not completely feeling a part of either her original country or her current country. This identity is the most challenging for newcomers, as it provides immigrants with the least support.

Nick described his identity in the way that I [first author] used to feel about myself. He said,

When you kind of think about it, you are a bit confused on who you are. In a way I don't feel Argentinian. At the same time, I do. In a way I don't feel American, but at the same time I do. In a way I feel like we have the advantage of being American because we don't take America for granted as a lot of white people do.

Nick suggests both an integrative mind-set and one that does not allow for integration. At the same time, he is not someone who would fit into the category of marginalization. Additionally, he provides a critique of those born in the United States, white citizens in particular, who take their privileges for granted.

There was a point in my life when I [first author] was confused about who I was. I knew that I did not belong in Argentina because I left at age six. I also felt that I did not belong in America because I was not a citizen. Given what the media have stated about immigrants, I have asked myself, "Who am I?" and "Where do I belong?" I finally 
understood that I am Argentinian because I was born there, but I am American because I was raised here. I speak Spanish and eat traditional Argentinian food at home. When it comes to my thoughts, feelings, and academics, I can better express myself in English. I do not think that the Argentinian culture and the American culture come into conflict in my life. I am not legally American, but I feel more American than I do Argentinian. If I were to be deported, I would have no sense of how to fit in.

\section{Discussion}

The purpose of this research was to examine participants' experiences of how DACA status affected their sense of national identity and belonging, and corresponding ability to integrate into U.S. society. Themes introduced barriers experienced by each of the participants: language, discrimination, school/financial challenges, equality, home and national affiliation. All participants gave their definition of who is an American and how they believed that they did or did not fit into that definition.

The participants in this study acculturated into American society by balancing aspects of their homeland culture with American culture. However, we found that it was not easy to place each participant within one of Berry's [3] categories. As discussed in the findings, participants exhibited aspects of assimilation, separation, marginalization, and integration. The sense of disconnection from the United States resulted from legal/political issues and social discrimination. Additionally, everyday realities explained in Edensor's [25] theory on national identity, such as problems obtaining a driver's license, work, travel, and financial aid prevented them from fully embracing an American identity. These challenges were in contrast to the ease with which their American peers could accomplish these tasks, taking such accomplishments for granted.

Studies similar to ours examined divided senses of identity and belonging, but they had different conclusions or they focused on different issues. For instance, Tafoya et al.'s [11] research see also $[15,16]$ on undocumented Latinos' examined connections between political activism and their social identities as Americans. Most of the participants in our study were not politically active. They were angry and crestfallen about the political actions of President Trump, with the result that they were politically disengaged. Similar to our research, participants in Tafoya's study were unaware of their undocumented status until, as adolescents, they applied for a job or higher education and faced barriers (see also Monico \& Duncan [12]; Rosenberg et al. [13]). Participants in these studies similarly described a lack of knowledge about their home countries and explained that they identified with American culture.

Participants were intent on receiving a degree from an institution of higher education and contributing to U.S. society. Stories such as theirs are important counters to the political and media rhetoric that undocumented migrants are in the United States to abuse the system of social welfare, for instance. Their narratives described numerous challenges to reaching those goals, as well as mistakes by university staff that were not knowledgeable about DACA. These university examples connect to previous research on institutional ignorance and pervasive invisibility [17]. Their work has a strong connection to the narrative of the 1st author's discussion of how she was treated by university staff personnel as she asked for assistance.

To strengthen our research, we recommend replication studies with more DACA students. We recognize that a limitation of this study is the small number of participants. Other researchers might also interview DACA holders from different countries.

On his first day in office (20 January 2021), President Joe Biden signed a presidential action to preserve and fortify DACA, a policy that his predecessor tried to repeal [32]. He has also moved to create legislation providing legal permanent residency for DACA recipients and other undocumented residents. The change in immigration policy holds hope for the over 640,000 DACA recipients who want to make the United States their permanent home. Participants in this study indicated that policies made them unable to fully embrace their desire to identify with being American. 
However, more than policy changes are needed to help children brought to the United States feel as though they belong. They need to feel accepted by those in their society. Although incomplete, research has provided evidence that political leadership influences public opinion [33,34]. As such, it will be interesting to track DACA recipients' beliefs about belonging and social acceptance during the Biden administration.

Author Contributions: S.P.: Conceptualization, Methodology, Formal analysis, Interviews, Writingoriginal Draft. J.M.: Writing — Literature review, Formal analysis, Review and Editing. All authors have read and agreed to the published version of the manuscript.

Funding: This research received no external funding.

Institutional Review Board Statement: The study was conducted according to the guidelines of the Declaration of Helsinki, and approved by the Institutional Review Board of the University of South Florida (protocol code Pro00035579, 28 May 2019).

Informed Consent Statement: Informed consent was obtained from all subjects involved in the study.

Conflicts of Interest: The authors declare no conflict of interest.

\section{References}

1. Schmid, C.L. Undocumented childhood immigrants, the Dream Act, and Deferred Action for Childhood Arrivals in the USA. Int. J. Sociol. Soc. Policy 2013, 33, 693-707. [CrossRef]

2. Aranda, E.; Vaquera, E.; Sousa-Rodriguez, I. Personal and cultural trauma and the ambivalent national identities of undocumented young adults in the USA. J. Intercult. Stud. 2015, 36, 600-619. [CrossRef]

3. Berry, J.W. Immigration, Acculturation, and Adaptation. Appl. Psychol. Int. Rev. 1997, 46, 5-34. [CrossRef]

4. Brown, C.S. School context influences the ethnic identity development of immigrant children in middle childhood. Soc. Dev. 2017, 26, 797-812. [CrossRef]

5. Cohen, J.A.; Kassan, A. Being in-between: A model of cultural identity negotiation for emerging adult immigrants. J. Couns. Psychol. 2018, 5, 133-154. [CrossRef]

6. Torres, R.M.; Wicks-Asbun, M. Undocumented students' narratives of liminal citizenship: High aspirations, exclusion, and "in-between" identities. Prof. Geogr. 2014, 66, 195-204. [CrossRef]

7. Berry, J.W.; Sam, L.D. Accommodating cultural diversity and achieving equity: An introduction to psychological dimensions of multiculturalism. Eur. Psychol. 2013, 18, 151-157. [CrossRef]

8. Ellis, L.M.; Chen, E.C. Negotiating identity development among undocumented immigrant college students: A grounded theory study. J. Couns. Psychol. 2013, 60, 251-264. [CrossRef]

9. Patler, C.; Pirtle, L. From undocumented to lawfully present: Do changes to legal status impact psychological wellbeing among Latino immigrant young adults? Soc. Sci. Med. 2017, 199, 39-48. [CrossRef]

10. Siemons, R.; Raymond-Flesh, M.; Auerswald, C.L.; Brindis, C.D. Coming of age on the margins: Mental health and wellbeing among Latino immigrant young adults eligible for Deferred Action for Childhood Arrivals (DACA). J. Immigr. Minority Health 2017, 19, 543-551. [CrossRef]

11. Tafoya, J.R.; Michelson, M.R.; Chávez, M.; Monforti, J.L. I feel like I was born here: Social identity, political socialization, and de Americanization. Lat. Stud. 2019, 17, 48-66. [CrossRef]

12. Monico, C.; Duncan, D. Childhood narratives and the lived experiences of Hispanic and Latinx college students with uncertain immigration statuses in North Carolina. Int. J. Qual. Stud. Health Well-Being 2020, 15, 1-17. [CrossRef]

13. Rosenberg, J.; Robles, S.; Agustin-Méndez, M.O.; Cathell, E.; Casasola, A. What happens to a dream deferred? Identity formation and DACA. Hisp. J. Behav. Sci. 2020, 42, 275-299. [CrossRef]

14. Benuto, L.T.; Casas, J.B.; Cummings, C.; Newlands, R. Undocumented, to DACAmented, to DACAlimited: Narratives of Latino students with DACA status. Hisp. J. Behav. Sci. 2018, 40, 259-278. [CrossRef]

15. DeAngelo, L.; Schuster, M.T.; Stebleton, M.J. California DREAMers: Activism, identity, and empowerment among undocumented college students. J. Divers. High. Educ. 2016, 9, 216-230. [CrossRef]

16. Chang, A.; Torrez, M.A.; Ferguson, K.N.; Sagar, A. Figured worlds and American dreams: An exploration of agency and identity among Latinx undocumented students. Urban Rev. 2017, 49, 189-216. [CrossRef]

17. Muñoz, S.M.; Vigil, D. Interrogating racist nativist microaggressions and campus climate: How undocumented and DACA college students experience institutional legal violence in Colorado. J. Divers. High. Educ. 2018, 11, 451-466. [CrossRef]

18. Katsiaficas, D.; Volpe, V.; Raza, S.S.; Garcia, Y. The role of campus support, undocumented identity, and Deferred Action for Childhood Arrivals on civic engagement for Latinx undocumented undergraduates. Child Dev. 2019, 90, 790-807. [CrossRef] [PubMed]

19. Bozorgmehr, M.; Bakalian, A.; Salman, S. Host hostility and nativism. In The Routledge International Handbook of Migration Studies; Gold, S.J., Nawyn, S.J., Eds.; Routledge: Oxfordshire, UK, 2013; pp. 189-201. 
20. Swan, R.S.; Clark-Ibanez, M. Perceptions of shifting legal ground: DACA and the legal consciousness of undocumented students and graduates. Thomas Jefferson Law Rev. 2017, 39, 67-92.

21. Abdelkader, E. Our country is full. Hum. Rights 2020, 45, 22.

22. Redfield, R.; Linton, R.; Herskovits, M.T. Memorandum for the study of acculturation. Am. Anthropol. 1936, 38, 149-152. [CrossRef]

23. Kang, S. Measurements of acculturation, scale formats, and language competence: Their implications for adjustment. J. Cross-Cult. Psychol. 2006, 37, 669-693. [CrossRef]

24. Rudmin, F.W. Critical history of the acculturation psychology of assimilation, separation, integration, and marginalization. Rev. Gen. Psychol. 2003, 7, 3-37. [CrossRef]

25. Edensor, T. National Identity, Popular Culture, and Everyday Life; Bloomsbury Academic Press: London, UK, 2002.

26. Creswell, J. Research Design: Qualitative, Quantitative, and Mixed Methods Approaches; SAGE: Los Angeles, CA, USA, 2014.

27. Yuksel, P.; Yildirim, S. Theoretical frameworks, methods, and procedures for conducting phenomenological studies in educational settings. Turk. Online J. Qual. Inq. 2015, 6. Available online: https:/ / dergipark.org.tr/tr/download/article-file/199867 (accessed on 8 March 2021).

28. Moustakas, C. Phenomenological Research Methods; Sage: Thousand Oaks, CA, USA, 1994.

29. Given, L.M. (Ed.) The SAGE Encyclopedia of Qualitative Research Methods; Sage: Thousand Oaks, CA, USA, 2008. [CrossRef]

30. Polkinghorne, D.E. Phenomenological research methods. In Existential-Phenomenological Perspectives in Psychology: Exploring the Breadth of Human Experience; Valle, R.S., Halling, S., Eds.; Plenum Press: New York, NY, USA, 1989; pp. 41-61.

31. Leavy, P. Research Design: Quantitative, Qualitative, Mixed Methods, Arts-Based, and Community-Based Participatory Research Approaches; Guilford Press: New York, NY, USA, 2017.

32. The White House. Preserving and Fortifying Deferred Action for Childhood Arrivals (DACA). Available online: https: / / www.whitehouse.gov/briefing-room/presidential-actions/2021/01/20/preserving-and-fortifying-deferred-action-forchildhood-arrivals-daca/ (accessed on 8 February 2021).

33. Druckman, J.N.; Jacobs, L.R. Who Governs? Presidents, Public Opinion, and Manipulation; University of Chicago Press: Chicago, IL, USA, 2015.

34. Matsubayashi, T. Do politicians shape public opinion? Br. J. Political Sci. 2012, 43, 451-478. [CrossRef] 